УДК 378.4:502.2:808(73)

\title{
SOCIAL CONTEXTS AND PRACTICAL AIMS OF LEARNING COMMUNICATION IN THE UNIVERSITY (SCIENTIFIC ANALYSIS OF THE POLL RESULTS WITHIN ACADEMIC ENVIRONMENT)
}

\author{
Gutsalo E. U., Matyash O. I.
}

У статті розглянуто проблему перспектив розвитку наукових комунікативних досліджень і комунікативної освіти в університетах. Академічна сфера суспільних, соціальних та гуманітарних наук традиційно представлена у структурі вищих навчальних закладів та їхніх навчальних програмах такими класичними гуманітарними дисциплінами, як лінгвістика, фрілологія, вивчення іноземних мов, журналістика, педагогіка, психологія, фрілософрія. Ці дисципліни глибоко укорінені і мають нормативний статус у системі вищої освіти, проте у багатьох університетах останнім часом набувають популярності програми із області соціології, політології, менеджмента, державного управління, бізнесу $і$ права, культурології, зв'язки з громадськістю. Проведене дослідження дає уявлення про те, як академічна спільнота презентує свої погляди щодо комунікації, як розуміє комунікативні процеси, якого значення надає основним концепиіям і проблемним питанням комунікології, чи уважає необхідним вивчення комунікації як дисципліни, а також які культурні традиції й дискурси виявляються у висловлюваннях викладачів. Автори роблять висновок про те, що інституціональна приналежність відіграє вирішальну роль у тому, як респонденти різних фракультетів концептуалізують комунікацію й розглядають їі наукові і практичні перспективи. Аналіз результатів опитування проводився 3 позицій соціокультурного підходу: емпіричні дані були проаналізовані у більш широкому культурному контексті, аби відслідкувати, як висловлювані під час опитувань погляди резонують із культурними переконаннями респондентів, практикою спілкування й традиціями.

Ключові слова: комунікація, комунікативні дослідження, комунікативна дисципліна, оглядовий аналіз, соціокультурна перспектива.

В статье рассмотрена проблема перспектив развития научных коммуникативных исследований и коммуникативного образования в университетах. C позиций социокультурного подхода дана характеристика концептуальных идей эмпирического исследования. Описаны результаты опроса преподавателей социальных и гуманитарных дисциплин университетов, представлен научный анализ ответов респондентов на некоторые вопросы, сделаны соответствующие выводы.

Ключевые слова: коммуникация, коммуникативные исследования, коммуникативная дисциплина, обзорный анализ, социокультурная перспектива.

This paper offers an analysis of a survey, conducted among faculty of universities on the topic of how communication, communication studies, and education are viewed today academia. While continuing discussions about communication and communication training are taking place, there are few empirical studies looking at the development of the discipline and communication education. With this in mind, the authors conducted a study to explore two questions: how educators view communication and communication studies; and how they view the need for communication education at the university level. This study provides initial insights into how academics express their views on communication and communication science - what language they use to discuss communication issues, what meanings they assign to the basic concepts and issues, and what cultural traditions and discourses inform their perspectives. Also, this study involves primarily the faculties of more traditional higher educational institutions representing the socalled psycho-pedagogical sector. It might be useful to extend this line of research to the faculties of more modern universities, representing new social departments and programs. As we can see from this study, institutional affiliations play a critical role in how different faculties conceptualize communication and view the 
prospects for communication research, and eventually for communication education. This analysis was undertaken from a sociocultural perspective: the empirical findings were analyzed in a broader cultural context to see how the expressed views resonate with broader cultural beliefs, practices, and traditions.

Key words: communication, communication studies (science), communication discipline, survey analysis, sociocultural perspective.

Formulation and justification of the relevance of the problem. The issue of communication and communication education in today's science, viewed from a sociocultural perspective, presents an interesting dilemma. During the past several decades, we have witnessed an increased interest in scholarly research, professional practices, and a higher education perspective toward what one may call a "communication agenda". Today, regional universities are offering communication-related programs, including specialized communication areas, such as Advertising and Public Relations and Linguistics and Intercultural Communication, which just a few decades ago did not exist. One can also see a growing number of communication and related courses elsewhere in the university curricula. The very terms communication (kommunikatsia), communication studies (kommunikativistika / kommunikologia), and communication competencies (kommunikativnie kompetentsii) not only have become an active part of the academic vocabulary, they have also become integrated into broader social discourse. The "communication agenda" has thus become a part of the discussions among various groups of scholars and practitioners. These discussions arise in traditional academic communities, in alternative intellectual circles, and in the business space.

One could claim that these trends seem to manifest a growing development and institutionalization of the study of communication as an academic field. However, can one really support this claim? What do we actually know about the development of communication as a discipline, particularly as manifested in academic communities in the regional universities, many of which still maintain a more traditional structure of learning? How can we even define that there is (or there is not) a "problem with communication education?" There is a striking lack of empirical research that could support our informed perspectives on the status of the development of communication as a discipline.

\section{Analisis of recent research and publications.}

The study implements a sociocultural approach and draws from a set of ideas (Baxter, 2011; Craig, 2008; Pearce, 2007; Shepherd, John, \& Striphas, 2006) which allow a look at "the problem of communication in society", or the formation of the discipline as a cultural discourse, or better yet, as an interplay of discourses about communication [2; 3 ; $4 ; 5 ; 11 ; 13]$.

The phenomenon of human communication, its nature, and role in the society has attracted a good many people thinkers within different disciplinary traditions: linguistics, philology, literary and arts studies (Mikhail Bakhtin, Dmitriy Likhachev); existential philosophy (Nickolai Berdyaev) and humanistic, psychology (Tamara Florenskaya); semiotics (Yury Lotman); methodology of systems thinking (Georgiy Schedrovitsky); and social perspective (Arkadiy Sokolov), just to name a few. Among these disciplinary perspectives and intellectual traditions, the psychological tradition particularly stands out. It was the work of renowned psychologists in the second half of the twentieth century (A. N. Leontiev, S. Rubinshtein, B. Lomov, A. A. Leontiev, L. Buyeva, A. Bodalev, V. Myasischev, B. Parygin, P. Yacobson, G. Andreyeva, M. Kagan, etc.), who examined the issue of communication in its broadest theoretical, philosophical, sociocultural, and sociopsychological context. This school of thought has been deeply integrated and remains influential in the academic curriculum for social science and humanities in universities.

Most work of those authors dates back to the second half of the previous century, and at that time, the general term used to define the phenomenon, both in the common language and academic discourse, was obshenie (pronounced obsh-yen-i-ye).

The purpose of the article. Based on this line of research and with this framework in mind, the authors decided to explore what perspectives on communication and 
communication studies exist in academia today, by posing the following research question: How do educators conceptualize communication and communication studies?

The maine material of the stuty. The academic field of Social Sciences and Humanities is traditionally represented in the structure of higher education institutions and their curricula by such classical humanities disciplines as linguistics, philology, language studies (including teaching foreign languages), journalism, psychology, pedagogy, and philosophy. These disciplines are deeply rooted and have a well-established status in the system of higher education. Their schools and departments (fakultety and kafedry), and their areas of training are still the most prevalent in the structure of regional universities all over the country. Recently, programs in sociology, management, public administration, business and law, culturology, and public relations have also become popular in regional universities (the situation with the leading national universities has been somewhat different).

The authors has undertaken an exploratory study to find out how communication, communication studies, and communication education are viewed today academia, particularly among faculty members at universities and institutions of higher education. The study particularly targets faculty members in the field of social sciences and humanities because they are the primary "intellectual force" responsible for educational practices and they are the ones who form and frame perspectives on a given discipline.

Survey question 1: How the participants understand communication. It is important to note that there are two words that denote communication: kommunikatsia and obshenie. Both words are translated into English as communication, but the first word has a latin origin, and the second word is of russian origin where the root also means "shared, having in common". In everyday discourse, the term kommunikatsia traditionally has been associated with the technical means of connection, while obshenie commonly means human interaction and connectedness. In recent decades, the meaning of the term kommunikatsia has broadened - it is often used in standard combinations such as intercultural communication, social communications, or communicative competencies. Thus, both terms kommunikatsia and obshenie are used quite often, and sometimes interchangeably. However, an ambiguity exists: it is not uncommon to hear questions or inquiries about how the two terms are different.

The results show that the respondents associate communication most frequently with four terms / concepts: obshenie (approximately $60 \%$ of responses), interaction (about $37 \%$ ); information, information forwarding and information exchange (about $22 \%$ ), and connection, connectedness (about $17 \%$ ).

Other associations include such words as dialogue, feedback, understanding, contacts, the other, discussion, empathy, togetherness/commonness, conversation, and speech. However, those associations are fairly infrequent and constitute $1 \%$ or less of all responses. It is interesting to note that while obshenie was named in this question most frequently, understanding, in contrast, was named only a few times.

Some respondents introduce setphrases, or clichés: intercultural communication, nonverbal communication, communication theory, communication competencies, communication culture, referring to them as commonly used either in their own disciplines or as a part of broader academic, or even everyday vocabularies. The use of such setphrases (like communication competencies) suggests that the terms have become an integral part of a regular academic vocabulary. However, it does not mean that people who use them can clearly describe what those words mean to them - and this is what some respondents openly admit in their comments.

Some participants gave a more extensive description of communication. For example: an ability to construct / structure relationships, an ability to explain one's own point of view (teacher of municipal governance); an ability to express one's own thoughts and listen to what a conversation partner has to say (teacher of english as a foreign language); an encounter and a conversation between persons, search for understanding and agreement (teacher of philosophy); a variety of different forms of relationships and obshenie between / among individuals and groups (teacher of philosophy); experiencing / living through, encounter, life, breathing, development, culture (teacher of psychology); communication is: two-sided, effective, correct, coherent (teacher of culturology). One can see an expected trend here: quite often, those definitions and elaborations represent the 
participants' disciplinary affiliations, and as such can be seen as projections of the participants' disciplinary identities. For example, teachers of foreign languages tend to identify communication with instrumental language skills: to conduct a conversation, to express one's own thoughts, and understand what the other has to say; while teachers of philosophy and psychology tend to express a broader view on communication as a characteristic of human existence.

Survey question 2: Obshenie versus kommunikatsia. As stated earlier, most scholars associate communication with obshenie, and survey item aimed at shedding more light on how the respondents see a difference between the two concepts. The results show that participants express a wide array of opinions and conceptualizations, which may be categorized into the following three perspectives:

1. Kommunikatsia is a broader category than obshenie; they relate as whole and part, obshenie being a form of kommunikatsia. The rationale for this approach is that "obshenie implies a direct contact between interacting individuals, while kommunikatsia can be also mediated" (teacher of philosophy); or "obshenie is an interpersonal communication, something which is more specific in relation to kommunikatsia" (teacher of sociology). This perspective was expressed most frequently by those who teach philosophy or have a social science background.

2. Obshenie is broader than kommunikatsia, it embraces kommunikatsia as a component. This perspective was expressed mostly by respondents who teach psychology and pedagogy, which is also representative of their disciplinary affiliation. As mentioned earlier, this perspective is rooted in a long-standing psychological intellectual tradition, and it was adopted by the Soviet theory of pedagogy. Pedagogy has been known as a discipline, the theoretical foundation of which was "based on" psychology. So, there is a reason why most faculties who represent the departments of pedagogy and pedagogical, psychology express this particular view.

An additional explanation of why obshenie is broader than kommunikatsia is provided by a psychologist: kommunikatsia can be viewed as "a situation of obshenie". In other words, this respondent views kommunikatsia as situational versus obshenie as immanent to human nature.

3. Kommunikatsia and obshenie are synonymous, they have close meanings and can be viewed as similar concepts, yet at the same time with their own connotations: obshenie characterizes interpersonal interactions, while kommunikatsia has an additional connotation as exchange of information; kommunikatsia is a scholarly term, obshenie is a more conversational, "humane" term; kommunikatsia denotes something more artificial, purposefully designed, intentional; obshenie is more natural, humane; kommunikatsia is technological, obshenie is closer to philosophy; kommunikatsia requires reflexivity and reflection, while obshenie does not; kommunikatsia is rational, and obshenie is more emotional; obshenie is something psychological; it has a stronger psychological component; kommunikatsia is goaloriented, purposive / purposeful; it has pragmatic expectations, while obshenie is not like that, sometimes it can be foolish ("have no sense"). "On the one hand, these terms can be viewed as synonymous; on the other hand, the term kommunikatsia seems to be used talks very seldom (mostly by specialists, although it's not clear of what kind), except for the phrase communication culture" (teacher of pedagogy).

4. Obshenie and kommunikatsia are two separate concepts (this perspective was expressed by those respondents who teach philosophy): kommunikatsia is first and foremost a process of transmitting information between two interconnected systems, including antropo-sociocultural systems; it is a process of coding and decoding information or meanings (teacher of philosophy); obshenie characterizes specifically the relationship between human subjects; it is a way of being, characterizing a person interconnected with other people. Obshenie cannot be reduced to just exchange of information or social and psychological contacts. It is a much more complex process (teacher of philosophy).

In summary, an analysis of responses shows that in participants' perceptions, the two concepts obshenie and kommunikatsia are associated with different sets of meanings and connotations. Kommunikatsia is associated mostly with information and information exchange, channels, technological dimensions, purposefulness, strategies, and effectiveness. It is also viewed as orderly, correct, or rule-governed, artificial, and 
pragmatic. Conversely, obshenie is associated with humans and humanness, human psychology, person-to-person connectedness, dialogue, feedback, and emotions. It is also viewed as being natural, not orderly, to the extent of being foolish and messy. One more distinction that can be drawn from responses is that kommunikatsia is viewed as situational (or, as we would define, syntagmatic), while obshenie as immanent (or paradigmatic).

One could posit that this conceptualization of obshenie by respondents is fairly close to the concept of interpersonal communication in English. However, unlike with interpersonal communication in the US tradition, where understanding of the other, otherorientedness, interconnectedness and interdependence are recognized as the basic cornerstone principles, the accounts on this question do not seem to frequently connect obshenie to understanding the other, taking the other's perspective. The terms understanding and mutual understanding, empathy and the other were referenced only a few times.

Along the same line, the approach to interpersonal communication in the USA embraces meaning as a key concept, and a whole vocabulary is built around it: meaningmaking, shared meanings, negotiating meanings, coordinated management of meanings, and so on.

Many respondents refer in their accounts to a structural model of obshenie traditionally established through the discipline of psychology. In that model, the process of obshenie is structured as having three dimensions or components: communicative (information transmission and exchange), interactional, and perceptual. This supports the conclusion that this theoretical perspective is still among the dominant ones in the academic discourse, particularly in the field of pedagogy, including foreign languages, and psychology. An information exchange model of communication also seems to be well adopted by many faculties (and may be considered as another communication-related discourse); yet, conceptually, it does not contradict, but rather extends the existing psychological model.

Many respondents (including the ones who do not represent psychology and pedagogy) associate kommunikatsia / communication with information and information transmission and exchange, which implies that the faculties' perspectives may not be informed by other theoretical perspectives and ideas about communication, such as transaction model, constitutive model, co-construction and negotiation of meanings, communication as a flow of social meanings, or ideas that emphasize the constructive and transformative role of communication.

So far, we can see that there is no emerging consensus on how the participants view kommunikatsia and obshenie. In fact, the presented views are often oppositional, and in terms of frequency, no perspective among the groups prevails over others. This indicates, among other things, that currently existing theories in humanities have not yet addressed this conceptual challenge by offering a comprehensive explication, elabration, and comparative analysis of the two concepts and that the theoretical work oof developing these constructs and perspectives still lies ahead.

Survey question 3: The value and need of studying communication. All respondents recognize positively, with no doubts that studying communication is important for both an individual and a society, and they bring up a whole spectrum of reasons why. Studying communication is generally viewed as a powerful resource to make things work better in all spheres of life and on all levels - national societal, international and intercultural, professional and career, personal relationships, and individual development and selfactualization. Thus, the respondents unanimously recognize the universal value of studying communication and its practical value. This practical value is often stated in the most general terms and categories: to improve professional relationships; to improve the level of communicative competence; to provide effective and productive obshenie; to construct the right relationships; to know and understand the processes of social life, to acquire communicative competence, etc.

As anticipated, most respondents emphasized the pragmatic need or purpose of studying communication: to improve obshenie (interactions and relationships), to be effective in building interactions and relationships, to optimize interpersonal relations, to be more productive, to have more successful cooperation and partnerships, to achieve goals. 
More than one-third of responses (about $35 \%$ ) emphasize that studying communication is instrumental "to make things better".

As far as the contexts - what things to improve - a broad scope of situations, purposes, and environments is outlined. The most frequently noted ones are: personal growth and professional purposes: to better understand the basics of social life and people around, to be successful, to be able to overcome communication failures, for selfactualization, for competent professional interactions; cultural and educational purposes: to improve individuals' communication competence and the level of communicative culture in the society; cooperation in society: for better cooperation, for building partnerships, and better relation-ships in different environments, for intercultural and international contacts.

Within this wide array of practical purposes and social contexts, the following points stand out:

1. The respondents show complete unanimity on this question: studying communication is undoubtedly important and has a broad social meaning and value.

2. Most respondents frame their accounts, why it is important to study communication, in fairly broad social categories: "to optimize the process of human interactions in different spheres of life and activity", "to enable the development of social competencies", "for self-development and self-actualization". In contrast, very few respondents define it in terms of everyday practical need: "to be able to identify the reasons for communication failures and the ways to overcome them" and "to learn different behavioral strategies and techniques to manage everyday life situations".

3. The majority of respondents use the perspective and language of their academic field to answer the question. The psychologists emphasize personal growth and selfactualization, pedagogues - acquiring necessary knowledge and skills, foreign language teachers - enabling competencies in intercultural communication.

4. Consistent with the previous responses, about $20 \%$ of respondents emphasize the information approach to the issue: it is important to study communication "in order to prevent information distortion, to understand better how the information exchange takes place and to know the causes, to be able to transmit information correctly". This further represents the information exchange discourse and confirms again that the corresponding model (communication as information exchange) is relatively well spread out among this academic community.

5. Along with the information exchange approach, a different vocabulary was used to answer the question. Some psychologists and representatives of applied social departments recurrently used phrases like "to effectively construct/build relationships, interactions, and communication". Such phrasings manifest that the authors associate com-munication with "active doing", work, activity and construction, and this interpretation may be viewed as some indication of "relational construction" approach.

Very few respondents speak about studying communication in the context of everyday situations, such as "to be able to identify the reasons for communication failures and the ways to overcome them", or "to learn different behavioral strategies and techniques to manage everyday life situations". This suggests that many respondents may not associate communication with applied research and may not envision this kind of research as helpful in addressing their everyday life problems.

Conclusions and directions for future research. This study provides initial insights into how academics express their views on communication and communication science - what language they use to discuss communication issues, what meanings they assign to the basic concepts and issues, and what cultural traditions and discourses inform their perspectives.

Overall, it is not clearly evident from these responses that faculty members associate communication with a practical discipline and applied research, focused on diverse communicative practices. Our assumption is that many educators are not aware of how much modern communication research contributes to managing social problems and as such, improving social interaction. Perhaps, had this knowledge been appropriated by them, their view on communication, both as practice and as an area of study would have been different.

Future research should broaden and diversify the sampling by engaging participants from other academic disciplines. Also, this study involves primarily the 
faculties of more traditional higher educational institutions representing the so-called psycho-pedagogical sector. It might be useful to extend this line of research to the faculties of more modern universities, representing new social departments and programs. As we can see from this study, institutional affiliations play a critical role in how different faculties conceptualize communication and view the prospects for communication research, and eventually for communication education.

This analysis was undertaken from a sociocultural perspective: the empirical findings were analyzed in a broader cultural context to see how the expressed views resonate with broader cultural beliefs, practices, and traditions.

Another important theme worth exploring within a sociocultural perspective is: how the existing social practices affect the development of communication disciplines in the country. We hope that the findings of this study, and the questions raised will serve as a stimulus for new empirically grounded interpretive and conceptual studies.

\section{References}

1. Andreyeva, G. Sotsialnaya psihologia [Social psychology] / G. Andreyeva. - Moskva : Nauka, 1994.

2. Baxter, L. Voicing relationships: A dialogic perspective / L. Baxter. - Thousand Oaks, CA: Sage, 2011.

3. Baxter, L. Engaging theories in interpersonal communication: Multiple perspectives / L. Baxter, \& D. Braithwaite (Eds.). - Thousand Oaks, CA: Sage, 2008.

4. Boyatzis, R. Transforming qualitative information: Thematic analysis and code development. Thousand Oaks, CA: Sage, 1998.

5. Craig, R. Communication in the conversation of disciplines / R. Craig // Russian Journal of Communication. - N 1(1). - S. 7-23. - 2008.

6. Kagan, M. Mir obschenia: Problema mezhsubyektnyh otnoshenii [The world of obshenie: The problem of intersubjective relations] / M. Kagan. - Moskva : Politizdat, 1988.

7. Kashkin, V. (2014). Russian communication studies: A semi-clandestine science. Russian Journal of Communication. - 2014. - N 6(1), - S. 89-92.

8. Leontiev, A. A. Psihologia obshenia [Psychology of obshchenie] / A. A. Leontiev. Moskva : Smysl, 1974/1997.

9. Littlejohn, S. Theories of human communication (10th ed.) / S. Littlejohn, \& K. Foss. Long Grove, IL: Waveland Press, 2010.

10. Parygin, B. Anatomia obshenia [Anatomy of obshchenie] / B. Parygin. - SPb. : izdatelstvo Mikhailova, 1999.

11. Pearce, W. B. Making social worlds: A communication perspective / W. B. Pearce. Malden, MA : Blackwell, 2007.

12. Sokolov, A. Metateoria sotsialnoi kommunikatsii [Metatheory of social communication] / A. Sokolov. - SPb. : Russian national library, 2001.

13. Shepherd, G. Communication as ... : Perspectives on theory / G. Shepherd, J. John, \& T. Striphas (Eds.). - Thousand Oaks, CA : Sage, 2006. 